\title{
Histopathological Spectrum of Breast Lesions in Association with Histopathological Grade Versus Estrogen Receptor and Progesterone Receptor Status in Breast Cancers : A Hospital Based Study
}

\author{
Mohan Rao Nandam ${ }^{1 *}$, Vissa Shanthi ${ }^{1}$, Bhavana Grandhi', Syama Sundara Rao Byna ${ }^{1}$, \\ Bheemaraju Venkata Vydehi ${ }^{1}$ and Jyothi Conjeevaram ${ }^{2}$ \\ ${ }^{1}$ Department of pathology, Narayana Medical College, Nellore, Andhra Pradesh, India \\ ${ }^{2}$ Department of social and preventive medicine, Narayana Medical College, Nellore, Andhra Pradesh, India
}

\begin{abstract}
Background: A retrospective study of 2-years duration from January 2015 to December 2016 was undertaken to evaluate the histopathological spectrum of breast lesions including both the benign breast lesions and malignant breast lesions. To evaluate the Estrogen receptor and Progesterone receptor status in breast cancer cases by using immunohistochemistry and is to correlate the histopathological grade with ER, PR status of breast cancer.
\end{abstract}

Methods: The histopathological findings of the 132 biopsied Specimens of all age groups and both sexes were studied and most of them were lumpectomy specimens and few were mastectomy specimens. IHC markers were applied on breast cancer cases.

Results: Out of the 132 cases benign breast lesions constituted $78.78 \%$ and malignant breast lesions $21.22 \%$. Among the benign breast lesions fibro adenoma was the commonest and among the malignant breast lesion, infiltrating ductal carcinoma was commonest. The peak incidence of benign breast lesion was in 11 to 40 years and malignant lesion in 41 to 70 years. Out of 22 cases of infiltrating ductal carcinoma, $27.27 \%$ cases showed both ER, PR positivity and $63.64 \%$ cases showed both ER, PR negativity. A significant association was seen between histologic grade and ER, PR status.

Conclusion: In our study fibro adenoma was the commonest benign breast lesion and infiltrating ductal carcinoma was the predominant malignant breast lesion. Among the breast cancers, both ER and PR negativity cases were predominant and low grade tumors were showing high ER, PR expression and high grade tumors were showing low ER, PR expression in our study.

Keywords: Breast Lesions, Fibro Adenoma, Infiltrating Ductal Carcinoma, Histopathological Grade, Immunohistochemistry.

\section{Introduction}

According to WHO statistics $2008,{ }^{[1]}$ malignant breast lesions comprises 1.38 million cases $(10.9 \%$ of total cancer cases). According to Indian statistics malignant breast lesion is the second most common malignancy in woman after carcinoma of cervix and is detected in 20 per 1,00,000 women. ${ }^{[2,3]}$ Fortunately, most of the breast lesions are diagnosed as benign breast lesions. ${ }^{[4]}$ Main aim of our study is to evaluate the Histopathological spectrum of breast lesions in patient attending the $\mathrm{NMCH}$, Nellore Andhra Pradesh, India,3

The spectrum of breast lesions consists of benign lesions including fibro adenoma, phyllodes tumor, Gynaecomastia, Breast abscess \& chronic mastitis, malignant lesions including ductal carcinoma, lobular carcinoma, colloid carcinoma and medullary carcinoma. Benign breast lesions incidence begins during the second decade of life and peaks in the fourth and fifth decades. But malignant breast lesions incidence increase after menopause. ${ }^{[5]}$

\section{Material and Methods}

The study was conducted in the department of pathology, $\mathrm{NMCH}$, Nellore, Andhra Pradesh, India from January 2015 to December 2016. 132 biopsy specimens were received. Among the 132 biopsy specimens most of biopsy specimen's were lumpectomy specimens and few were mastectomy specimens. These biopsy specimens were fixed in $10 \%$ formalin solution for 24 hours. The tissue was processed routinely, and paraffin embedded tissue were cut on microtome to the thickness of 4 microns. The sections were stained with Haematoxylin and Eosin stain and reported. Out of 28 cases of breast cancers, 22 cases were infiltrating ductal carcinomas which were histologically 
graded according to Modified Bloom-Richardson-Elston grading system. After that, breast cancer tissue block were selected for IHC evaluation (ER and PR status).

Statistical Analysis: Data collected was entered in MS Excel and analyzed using SPSS-Version 22.0. Percentages and chi-square values were calculated. A P value of 0.05 was taken as significance.

\section{Result}

132 cases of breast lesions were studied over a period of Two years from January 2015 to December 2016. The commonest presenting symptom in breast lesion was lump in the breast. Out of 132 cases, 20 cases were males and 112 cases were females. Out of 20 cases of males, majority of cases were Gynaecomastia. Among 132 cases, benign breast lesions consistituted 104 cases $(78.78 \%)$ and malignant breast lesions 28 cases $(21.22 \%)$. The youngest male (14 years) was diagnosed with gynaecomastia and the youngest female (12 years) was diagnosed with fibro adenoma breast. The ages of the cases ranged between 11 years to 80 years. The peak age of occurrence to the benign lesions was found to be in between 11-40 years, youngest case detected as fibro adenoma at 12 years of age. The peak age of occurrence of the malignant lesion was found to be in between 41-60 years, youngest case diagnosed as medullary carcinoma at 35 years of age, and oldest case diagnosed as a mucinous carcinoma at 80 years of age.

Among the 104 cases of benign breast lesions, 78 cases $(75 \%)$ were of fibro adenoma, 2 cases $(1.92 \%)$ were of benign phyllodes, 14 cases $(13.46 \%)$ were of Gynaecomastia, 4 cases (3.85\%) were of breast abscess and
6 cases $(5.77 \%)$ were of chronic inflammatory pathology. Among the benign breast lesion, fibro adenoma was the most common lesion [Table 1].

Among the 28 cases of malignant breast lesions, 22 cases (78.57\%) were of infiltrating ductal carcinoma [Figure $1], 2$ cases $(7.14 \%)$ were of medullary carcinoma, 2 cases (7.14\%) were of lobular carcinoma and 2 cases $(7.14 \%)$ were of mucinous carcinoma. Among the malignant breast lesions, infiltrating ductal carcinoma was the most common lesion [Table 1].

Among the 22 cases of infiltrating ductal carcinoma, the commonest grade was grade 2 accounting to $72.73 \%$ followed by grade 3 and grade 1 with $18.18 \%$ and $9.09 \%$ respectively. Among the 22 cases of infiltrating ductal carcinoma, 10 cases of grade 2 breast carcinoma were in age group of 41-50 years, 2 cases of grade 2 breast carcinoma were in age group of 51-60 years, 2 cases of grade 1, 4 cases of grade 2 and 4 cases of grade 3 breast carcinoma were in age group of 61-70 years [Table 2] Out of 22 cases of infiltrating ductal carcinoma lesions were studied for the ER, PR expression. The number of tumors positive for both ER and PR [Figure $2 \& 3$ ] were 6 (27.27\%). The number of tumors for ER positive and PR negative was two cases $(9.09 \%)$. The number of tumors negative for both ER and PR were 14 (63.64\%).

Among the 22 cases of infiltrating ductal carcinoma $50 \%$ of grade 1 cases were ER positive and PR positive, 25\% of grade 2 and $25 \%$ grade 3 were also ER positive and PR positive. $68.75 \%$ of grade 2 and $75 \%$ of grade 3 tumors were both ER negative and PR negative [Table 3].

Table 1: Different histopathological lesions in Benign Breast lesions \&malignant breast lesions

\begin{tabular}{|l|c|c|}
\hline \multicolumn{2}{|c|}{ Benign Breast lesions } \\
\hline Histopathological diagnosis & Number of cases & Percentage of benign Breast lesions \\
\hline 1.Fibroadenoma & 78 & $75 \%$ \\
\hline 2.Benign Phyllodes & 2 & $1.92 \%$ \\
\hline 3.Gynaecomastia & 14 & $13.46 \%$ \\
\hline 4.Breast abscess & 4 & $3.85 \%$ \\
\hline 5.Chronic inflammatory pathology & 6 & $5.77 \%$ \\
\hline Total & $\mathbf{1 0 4}$ & $\mathbf{1 0 0 \%}$ \\
\hline Malignant breast lesions & Number of cases & Percentage of Malignant breast lesions \\
\hline Histopathological diagnosis & 22 & $78.57 \%$ \\
\hline 1.Infiltrating ductal carcinoma & 2 & $7.14 \%$ \\
\hline 2.lobular carcinoma & 2 & $7.14 \%$ \\
\hline 3.Medullary carcinoma & 2 & $\mathbf{7 . 1 4 \%}$ \\
\hline 4.Mucinous carcinoma & $\mathbf{2 8}$ & $\mathbf{1 0 0 \%}$ \\
\hline Total & \multicolumn{2}{|}{} \\
\hline
\end{tabular}


Table 2: Correlations between age wise distribution and grade of breast carcinomas

\begin{tabular}{|c|c|c|c|c|c|}
\hline s.no & Age & Grade 1 & Grade 2 & Grade 3 & Total \\
\hline 1 & $41-50$ & $-(0 \%)$ & $10(62.5 \%)$ & $-(0 \%)$ & $10(45.5 \%)$ \\
\hline 2 & $51-60$ & $-(0 \%)$ & $212.5 \%$ & $-(0 \%)$ & $2(9 \%)$ \\
\hline 3 & $61-70$ & $2(100 \%)$ & $4(25 \%)$ & $4(100 \%)$ & $10(45.5 \%)$ \\
\hline Total & & $\mathbf{2 ( 1 0 0 \% )}$ & $\mathbf{1 6}(\mathbf{1 0 0} \%)$ & $\mathbf{4 ( 1 0 0 \% )}$ & $\mathbf{2 2 ( 1 0 0 \% )}$ \\
\hline
\end{tabular}

There is statistically significant difference among the grades when compared to the different agent age groups $(p=0.042)$.

Table 3: Association of IHC Hormone receptor status with grade of Breast carcinomas

\begin{tabular}{|l|c|c|c|}
\hline IHC Hormone receptor status & Grade 1(\%) & Grade 2(\%) & Grade 3(\%) \\
\hline ER+/PR+ & $1(50 \%)$ & $4(25 \%)$ & $1(25 \%)$ \\
\hline ER+/PR- & $1(50 \%)$ & $1(6.25 \%)$ & 0 \\
\hline ER-/PR+ & 0 & 0 & $3(75 \%)$ \\
\hline ER-/PR- & & $11(68.75 \%)$ & $4(100 \%)$ \\
\hline Total & $2(100 \%)$ & $16(100 \%)$ & 0 \\
\hline
\end{tabular}

Table 4: Comparative study of spectrum of Benign breast lesions \& malignant breast lesions

\begin{tabular}{|c|c|c|c|c|}
\hline \multicolumn{5}{|c|}{ Benign breast lesions } \\
\hline s.no & Benign lesions & Malik et al (2003)(\% benign). & $\begin{array}{l}\text { Kulkarni S.et al (2009)(\% } \\
\text { benign).[15] }\end{array}$ & $\begin{array}{l}\text { Our study } \\
\text { ( } \% \text { benign) }\end{array}$ \\
\hline 1 & Fibro adenoma & 55.0 & 62.32 & 75 \\
\hline 2 & Benign phyllodes & 1.27 & 1.45 & 1.92 \\
\hline 3 & Gynaecomastia & - & - & 13.46 \\
\hline 4 & Breast abscess & - & 1.45 & 3.85 \\
\hline 5 & Chronic inflammatory lesion & - & - & 5.77 \\
\hline \multicolumn{5}{|c|}{ Malignant breast lesions } \\
\hline S.no & Malignant lesions & $\begin{array}{l}\text { Malik et al (2003) } \\
\text { (\%malignant). }{ }^{[14]}\end{array}$ & $\begin{array}{l}\text { Kulkarni S.et al (2009) } \\
\text { (\%malignant). }{ }^{[15]}\end{array}$ & $\begin{array}{l}\text { Our study } \\
(\% \text { malignant })\end{array}$ \\
\hline 1 & Infiltrating Ductal carcinoma & 88.20 & 84.85 & 78.57 \\
\hline 2 & Infiltrating Lobular carcinoma & 3.21 & 3.03 & 7.14 \\
\hline 3 & Mucinous carcinoma & 0.64 & 3.03 & 7.14 \\
\hline 4 & Medullary carcinoma & 2.57 & - & 7.14 \\
\hline
\end{tabular}

Table 5: Comparative incidence of frequency of grade of Breast carcinomas

\begin{tabular}{|c|c|c|c|c|c|c|}
\hline $\begin{array}{c}\text { Grade of } \\
\text { the tumor }\end{array}$ & $\begin{array}{c}\text { Azizun-Nisa } \\
\text { et al } \\
\text { (2008). }{ }^{[17]}\end{array}$ & $\begin{array}{c}\text { Adedayo et } \\
\text { al (2009). }{ }^{[18]}\end{array}$ & $\begin{array}{c}\text { Suvarchala } \\
\text { et al } \\
\text { (2011). }{ }^{[19]}\end{array}$ & $\begin{array}{c}\text { Ambroise } \\
\text { et al } \\
\text { (2011). }{ }^{[20]}\end{array}$ & $\begin{array}{c}\text { Ghosh } \\
\text { et al } \\
\text { (2011). }{ }^{[21]}\end{array}$ & $\begin{array}{c}\text { Geethamala k } \\
\text { et al (2014). }{ }^{[2]}\end{array}$ \\
\hline 1 & 6.7 & 21.2 & 28.12 & 9.4 & 0.3 & 19 \\
\hline 2 & 55.3 & 38.4 & 42.18 & 57.4 & 15.9 & 54 \\
\hline 3 & 38.0 & 35.9 & 29.69 & 33.3 & 75.4 & 27 \\
\hline
\end{tabular}




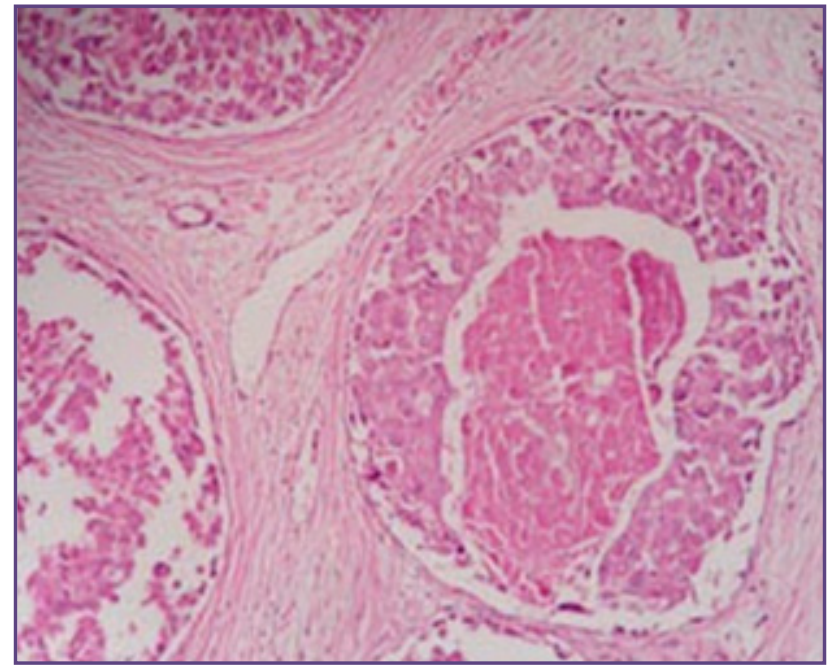

Fig. 1: Photomicroscopic picture of Infiltrating of ductal carcinoma (H\&E, 400X).

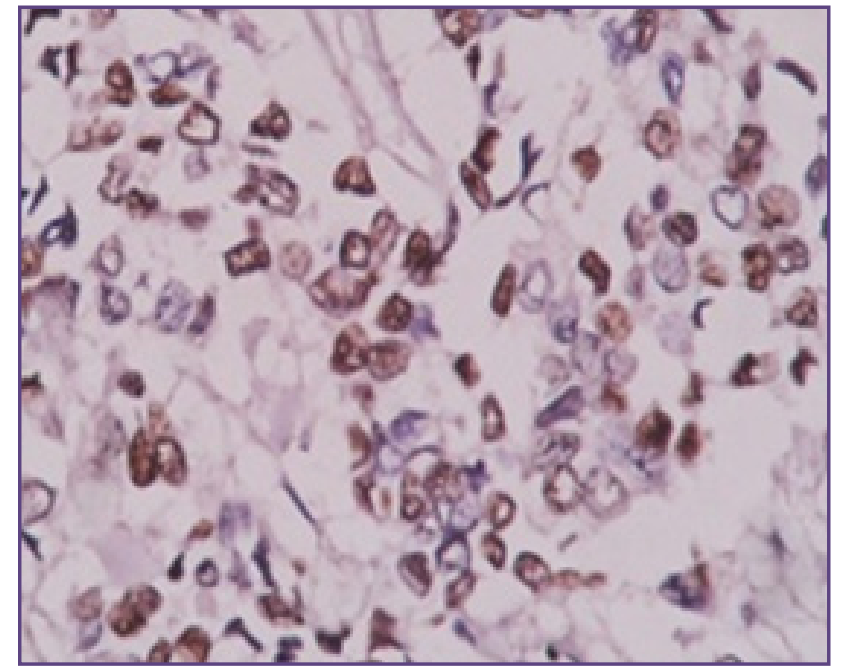

Fig. 2: Photomicroscopic picture of ER positive breast carcinoma $(400 X)$.

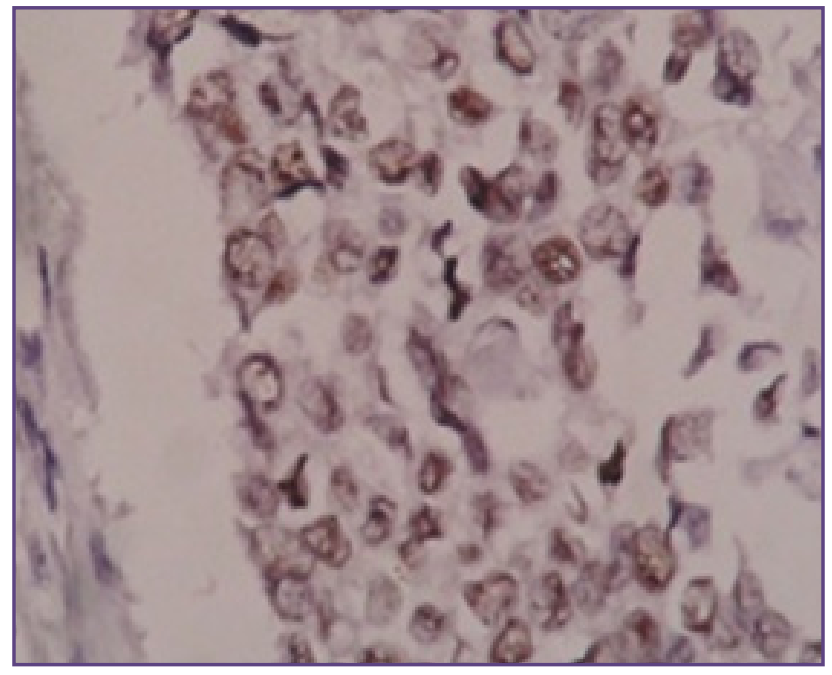

Fig. 3: Photomicroscopic picture of PR positive breast carcinoma (400X)

\section{Discussion:}

The breasts are composed of specialized epithelium and stroma that may give rise to both benign and malignant lesions. The human breast contains six to ten major ductal systems. The keratinizing squamous epithelium of the overlying skin dips into the orifices at the nipple and then abruptly changes to a double layered cuboidal epithelium lining the ducts. Successive branching of the large ducts eventually leads to the terminal duct lobular unit.

Two cell types lining the ducts and lobules are luminal epithelial cells overlaying the epithelial cells. Spectrums of breast lesions consist of benign lesions and malignant lesions. Most common benign breast lesions are fibro adenoma, phyllodes tumor, mastitis and breast abscess.
Most common malignant lesion are ductal carcinoma, lobular carcinoma, tubular carcinoma, mucinous carcinoma, medullary carcinoma, papillary carcinoma and metaplastic carcinoma.

Breast lesions are more predominance among females when compared to males and histopathological spectrum of breast lesion and their etiology varies among different countries and ethnic group. ${ }^{[6]}$ Benign breast lesions are more predominant as compared to malignant breast lesion as seen throughout the world. ${ }^{17}$ Risk factors for both benign breast lesions and malignant breast lesions include multiparty, low parity, low age at first child birth and late menopause, highlighting the fact towards excessive circulating estrogen. ${ }^{[8,9]}$ 
In our study, benign breast lesions comprised $78.78 \%$ of the total lesions and malignant lesion $21.22 \%$. The percentage of malignant breast lesions appears to be higher than that in the west $(10 \%)$ and nearer to Africa $(21 \%) .{ }^{[10,11]}$

In our study most common benign breast lesion was found to be fibro adenoma and most common malignant breast lesion was infiltrating ductal carcinoma. Similar results were noted in the other studies. ${ }^{[14,15]}$

In our study, among the benign breast lesions, incidence of fibro adenoma is $75 \%$ which is higher than the Malik R study (55.0\%) and Kulkarni s study $(62.32 \%) .{ }^{[14,15]}$ The incidence of benign phyllodes is $1.92 \%$ which is nearly compatible with Malik R study $(1.27 \%)$ and Kulkarni S study $(1.45 \%)^{[14,15]}$ The incidence of gynaecomastia is $13.46 \%$ among benign breast lesion. The incidence of Breast abscess is $3.85 \%$ which is higher than the Kulkarini $\mathrm{S}$ study (1.45\%). ${ }^{[15]}$ Incidence of chronic inflammatory lesion is $5.77 \%$ [Table 4 ].

In our study, among the malignant breast lesion, incidence of infiltrating ductal carcinoma is $78.57 \%$ which is lower than the Malik R study (88.20\%) and Kulkarini S study (84.85\%). ${ }^{[14,15]}$ Incidence of medullary carcinoma is $7.14 \%$ which is higher than the Malik R study $(2.75 \%)$.Incidence of lobular carcinoma is $7.14 \%$ which is higher than the Malik R study (3.21\%) and Kulkarini S study (3.03\%). ${ }^{[14,15]}$ Incidence of mucinous carcinoma is $7.14 \%$ which is higher than the Malik R study $(0.64 \%)$ and Kulkarini S study $(3.03 \%){ }^{[14,15]}$ [Table 4].

In our study incidence of benign breast lesion is $78.78 \%$ and malignant breast lesion is $21.22 \%$ which is nearly similar to U R Singh et al 2009, Rasheed A et al 2009-2011, and Malik et al 2003 studies. [12, 13, 14,]

In our study, the number of tumors positive for both ER and PR was $27.27 \%$ which is nearly similar to Thakral et al 2016 study (25.64\%). ${ }^{[16]}$ In our study the number of tumors for ER positive and PR negative was $9.09 \%$ which is higher than the Thakral et al 2016 study (5.98\%). ${ }^{[16]}$ In our study, the number of tumors negative for both ER and PR was $63.64 \%$ which is nearly similar to Thakral et al 2016 study $(63.25 \%){ }^{[16]}$

In the present study majority of breast cancers were grade $2(72.73 \%)$ followed by grade $3(18.18 \%)$ and grade $1(9.09 \%)$ which is in concordance with Azizun- Nisa et al 2008 study, ${ }^{[17]}$ Adebayo et al 2009 study, ${ }^{[18]}$ Suvarchala et al 2011 study, ${ }^{[19]}$ Ambroise et al 2011 study, ${ }^{[20]}$ and Geethamala k et al 2014 studies, ${ }^{[22]}$ except for one study by Ghosh et al 2011 having more of grade 3 tumors (75.4\%) [Table 5]. [21]
In the present study immunohistochemistry revealed $27.27 \%$ of ER positive / PR positive and $63.64 \%$ of ER negative / PR negative. These results were in concordance with Survachala et al 2011 study. ${ }^{[19]}$ In the present study significant co-relation was established between ER/PR hormone receptor statuses and grading of tumor. $50 \%$ of grade $1,25 \%$ of grade 2 and $25 \%$ grade 3 tumors were ER positive /PR positive. $68.75 \%$ of grade 2 and $75 \%$ grade 3 tumors were ER negative/PR negative. Our study was in concordance with Geethamala k et al 2014 study. ${ }^{[22]}$

\section{Conclusion}

Our study comprised 132 cases of breast lesions. The cases presented to Narayana Medical College \& Hospital, Nellore. The biopsy specimens were then evaluated histopathologically, and 22 cases were analyzed by immunohistochemistry. In our study the most common histopathological type of benign breast lesion was fibro adenoma ( 78 cases, $75 \%$ of the total benign breast lesion). The most common histopathological subtype of breast malignancy was infiltrating ductal carcinoma-NOS type (22 cases, $78.57 \%$ of the total cases with malignant lesion). Grade 1 tumors (low grade) were showing higher ER, PR expression .Grade 3 tumors (high grade) were showing lower ER, PR expression. Tumor grading highly correlates with the survivor rate and receptor status predicts the response to hormonal therapy.

\section{Acknowledgement}

The authors are thankful to the Miss. D. Padmaja B.tech and all the faculty of department of pathology, Narayana Medical College and Hospital, Nellore.13

\section{References}

1. Feraly J, Shin HR, Bray F, Forman D, Mathers C, Parkin DM. Estimates of worldwide burden of cancer in 2008. Globocan 2008; Int J cancer 2010 Dec 15;127(12):2893-917.

2. Desai M. Role of obstetrician and gynecologist in management of breast lump. J Obstet Gynaecol India 2003; 53:389-91.

3. Sharkey FE, Craig Allred DC, Valente PT, Damjanov I, Linder J's. Anderson pathology.10thed. st.Louis:Mosby;1996.P.2354-85.

4. Kumar, Abbas, Fausto, Robbins and Cotran Pathologic Basis of Disease. The Breast. 7th ed.Philadelphia: Elsevier: P.1119-1154.

5. Merih Guray, Aysegual A shin. Benign breasts Disease; Classification, diagnosis and management; The Oncologist; 2006; 11:435-449.

6. Siddiqui M, Kalyani N, Gill M, pervez S, Muzaffar S, Aziz S, Setna Z, Isar M, Hasan S. Breast disease: a histopathological analysis of 3279 cases at a tertiary care centre in Pakistan . J Park Med Assoc 2003:53(3):94-97. 
7. Mansoor I: Profile of female breast lesions in Saudi Arbia. JPMA 2001; 51(7):243-246.

8. Hislop T, Elwood J: Risk Factors for benign breast disease: a 30-year cohort study. Can Med Assoc J 1981; 124(3):283.

9. Parazzini F, La Vecchia C, Franceschi S. Decarli A, Gallus G, Regallo M, Liberati A, Tognoni G. Risk factors for pathologically confirmed benign breast disease. Am J Epidemiol 1984; 120(1):115-122.

10. Ellis $\mathrm{H}$ and Cox P J, Breast problems in 1000 consecutive referrals to surgical out -patients. Post grad Med J 1984 Oct: 60(708); 653-656.

11. Oluwule SF, Fadirm OA, odesammi WO. Diseases of the breast in Nigeria. Br J Sur 1987:74(7);582-585

12. Singh UR, Thakur AN, Shah SP, Mishra A. Histo morphological spectrum of breast diseases. J Nep Med Assoc 2000:39:338-3

13. Rasheed A, Sharma S, Mohsin -ul-Rasool, Bashir S, Hafiz A, Bashir N. A three year study of breast lesions in women aged 15-70 years in a Tertiary care hospital. Schloars journal of applied Medical sciences 2014:2(1B):166-168

14. Malik R, Bhardwaj VK. Breast lesions in young female. A 20 year study for significance of early recognition. Indian $\mathrm{J}$ path Microbiol 2003;46(4):559-562

15. Kulkarini $\mathrm{S}$ et al. Histopathological spectrum of breast lesions with reference to uncommon cases: Obs and Gynae of India Sept - Oct 2009;59(5):444-452
16. Thakral A, Daveshwar M. Histomorphological study of a spectrum of breast diseases $\mathrm{n}$ association with immunohistochemistry in Vododara, Gujarat, India. Int J Sci stud 2016:4(9):44-54.

17. Azizun - Nisa, Bhurgi Y, Raza F, kayani N. Comparison of ER, PR and HER-2/neu (C-erb B 2) reactivity pattern with histologic grade, tumor size and lymph node status in breast cancer. Asian Pac J cancer prev 2008:9:553-6.

18. Adedayo AO, Engel JM, Greenlee RT Mukesh BN. Breast cancer subtypes based on ER/PR and Her 2 Expression: Comparison of Clinic pathologic features and survival, Clin Med res. 2009; 7:4-13.

19. Suvarchala SB, Nagheshwararao R. Carcinoma BreastHistopathological and hormone receptors correlation. J Biosci Tech 2011:2; 340-48.

20. Ambroise M, Ghosh M, Mallikarjun VS, Kurian A. Immunohistochemical profile of breast cancer patients at a tertiary care hospital in south India immunohistochemical profile of breast cancer patients tertiary care hospital in south india. Asian pacific J cancer Prev 2011; 12:625-629.

21. 21.Ghosh J, Gupta s, Desai S. Shet T, Radhakrishnan S, Suryavanshi $\mathrm{P}$ et al . Estrogen, Progesterone and HER 2 receptor expression in breast tumors of patients and their usage of HER 2 targeted therapy, in a tertiary care centre in India. Indian J cancer 2011; 48:391-6

22. Geehamala $\mathrm{k}$ et al. histopathological grade versus Hormone receptor in breast carcinoma IJBR 2015;6(07); 466-471.

*Corresponding author:

Dr. N.Mohan Rao, Associate Professor, Department of Pathology Narayana Medical College, Nellore, Andhra Pradesh-524003, India

Phone: +91 9849229201

Email: nmr2020kmc@gmail.com

Date of Submission : 28.02.2017

Date of Acceptance : 24.06.2017

Financial or other Competing Interests: None.

Date of Publication : 25.10.2017 